\title{
Elaboration and sensorial evaluation of jelly and fruit crystallized cactus pear (Opuntia ficus-indica Mill)
}

\author{
Elaboración y evaluación sensorial de mermelada y fruta confitada \\ obtenida de nopal tunero (Opuntia ficus-indica Mill.)
}

\author{
João José da Silva Júnior ${ }^{1 *}$, Ricardo Luis Cardoso ${ }^{2}$, Antonio Augusto de Oliveira Fonseca ${ }^{2}$, \\ Ediclan Soares Machado ${ }^{2}$
}

\begin{abstract}
This study aimed at the elaboration and the sensorial evaluation of cactus pear fruit jelly and crystallized cactus pear fruit. The jelly obtained presented the following composition: reducing sugars $21.6 \%$; $\mathrm{pH} 3.07$; soluble solids $69.2{ }^{\circ}$ Brix; titrated acidity $0.63 \%$ (citric acid) and humidity $23.5 \%$. The sensory analysis was accomplished by a team of 20 non trained judges with ages between 20 and 50 years who evaluated the attributes global impression, aroma, flavor, color, texture and purchase intention, using a hedonic method with a nine-point scale from [9] liked very much to [1] disliked very much The results obtained showed that color was the attribute that showed the best acceptance for the judges with an average of 8.2. The attribute global impression obtained an average of 8.0, aroma 7.5, flavor 7.7, and texture 8.1. In the parameter purchase intention, all the judges declared that they would buy the product.

To obtain the crystallized fruit, fresh fruit was washed and separated into pulp and peel. The treatments were as follows: T01, pulp with addition of $0.2 \% \mathrm{CaCl}_{2} ; \mathrm{T} 02$, pulp without $\mathrm{CaCl}_{2}$ addition and $\mathrm{T} 03$, peel without $\mathrm{CaCl}_{2}$ addition, which were cooked in sugar syrup (sucrose) and an initial glucose concentration of $20 \%$ and gradually increasing sugar by $10 \%$ every 24 hours until saturation (70 \% sugar). The following physical-chemical analyses were carried out: $\mathrm{pH}$, total soluble solids (TSS) and total titratable acidity (TTA) and sensory analysis measured in a 9-point structured hedonic scale (from dislike extremely to like very much) among 30 consumers. Results were submitted to statistical analysis using the SISVAR software. The physical-chemical characteristics of $\mathrm{pH}$, TSS and TTA for treatment T01 were 5.27, 40.13 and $0.05 \%$, respectively, for the T02 treatment the pH was 5.54, TSS 59.38 and TTA $0.05 \%$, and for the T03 treatment the pH was 5.47 , TSS 47.5 and TTA $0.06 \%$. The treatment without calcium chloride received the best grades for the sensorial attributes evaluated. The results demonstrate that the intention of buying of the consumers was $48.39 \%$ for the treatment without calcium chloride.
\end{abstract}

Key words: crystallization, hedonic scale, $\mathrm{CaCl}_{2}$, physical-chemical characteristics.

\section{RESUMEN}

Este trabajo está dirigido a la elaboración y evaluación sensorial de la mermelada obtenida de frutas del nopal tunero y frutas confitadas del nopal. La gelatina obtenida presenta la siguiente composición: azúcares reductores, 21,6\%; pH, 3,07; sólidos solubles, 69,2 ${ }^{\circ}$ Brix; acidez titulable, 0,63\% (ácido cítrico), y la humedad, 23,5\%. Del análisis sensorial se llevó a cabo por un equipo de 20 jueces no entrenados con la edad entre 20 y 50 años que evaluó los atributos de la impresión global, aroma, sabor, color, textura, la intención de compra, por el método de la escala hedónica de nueve puntos "gustó mucho" [ 9] y "me disgustó mucho" [1] Los resultados obtenidos mostraron que el color era atributo que presentó mayor aceptación de los jueces con un promedio de 8,2. La impresión de atributos globales obtenidos promedio de 8,0, 7,5 aroma, sabor 7,7, 8,1 y la textura. En la intención de compra de parámetros, todos los jueces declararon que iban a comprar el producto. Para obtener los frutos de las frutas confitadas, se lavaron y se separaron la pulpa de la cáscara. Los tratamientos fueron los siguientes: T01, la pulpa con la adición de 0,2\% de $\mathrm{CaCl}_{2}, \mathrm{TO2}$, pulpa sin $\mathrm{CaCl}_{2}$ la suma y la T03, la cáscara $\sin \mathrm{CaCl}_{2}$ Además, fueron cocinados en jarabe de azúcar ( sacarosa) con una concentración de glucosa inicial de $20 \%$ y aumentada gradualmente $10 \%$ de azúcar cada 24 horas hasta la saturación (70\% de azúcar). El siguiente análisis fisicoquímico se llevó a cabo: pH, sólidos solubles totales (SST) y acidez total tritable (TTA) y el análisis sensorial se mide en una escala de 9 puntos hedónica estructurada de "no gusta" a "me gusta mucho" entre los 30 consumidores. Los resultados fueron sometidos a análisis estadístico utilizando el software SISVAR. Las características fisicoquímicas de pH, TSS y TTA para el tratamiento T01 fueron 5,27, 40,13 y 0,05\%, respectivamente, para el tratamiento T02, el $\mathrm{pH}$ fue 5,54, 59,38 y TTA del 0,05\%, y para el tratamiento T03, el pH fue de 5,47, SST de 47,5 y TTA de 0,06\%. El tratamiento sin cloruro de calcio presenta mejores calificaciones de los atributos sensoriales evaluados. Los resultados demuestran que la intención de compra de los consumidores fue 48,39\% para el tratamiento sin cloruro de calcio.

Palabras clave: cristalización, escala hedónica, $\mathrm{CaCl}_{2}$, características fisicoquímicas.

\footnotetext{
1 Department of Agricultural Engineering-UFLA, C.P. 32270000 , Lavras-MG, Brazil.

2 Center of agrarian environmental and biological Science-UFRB, Cruz das Almas-Ba

* Corresponding author: jjsjunior1@yahoo.com.br
}

Fecha de Recepción: 22 Agosto, 2011.

Fecha de Aceptación: 23 Mayo, 2013. 


\section{Introduction}

Brazil is one of the three larger world producers of fruits, something around 39 million tons a year. This elevated production of different varieties of fruitful native and exotic adapted, it is consequence of the extension of the territory and your insert, largely, in the tropical and temperate climate zones (Granada et al., 2004).

Among them fruit bowl potentials, we can also mention the cactus pear fruit that in some countries as Mexico and Sicily are so well consumed as the banana in Brazil and peach in Italy; presenting a rich composition in mineral salts as calcium, potassium, magnesium and sodium and vitamins to example of the vitamin $\mathrm{C}$, that overcomes some fruits as the watermelon and grapes (Manica,2002). Away in some countries to example of Brazil, the use of the cactus pear is almost that exclusively for animal ration; in some areas, your fruits are consumed in the form of juices, sweet and fruits dry, representing an additional source in the income of the small producer. As your fruits present problems in the conservation, and in crop period the losses are intensified by lack of technological alternatives, the processing of your fruits in the jelly form presents as a quite viable form joining value to the same. The jelly is a product obtained either in pieces of the pulp or of the juice of fruits for the cooking of the whole fruits, added of sugar and water and concentrated until the gelatinous consistence. It can be added glucose or inverted sugar to check shine to the product, being tolerated the acidulates addition and pectin to compensate any deficiency in the natural content of pectin or of acidity of the fruit. The syrup should be concentrated until the tenor of soluble solids enough so that it happens the jellies during the coolding. (Jackix, 1988). The consistence should be such that, when extracted of your recipient, be capable to stay in the state semi-solid. An appropriate combination of those components, in the quality and in the placement order during the processing, it should be respected (Albuquerque et al.,1996).

Crystallization process, also known as sugar saturation or glazing, involves the gradual substitution of humidity of the tissues by sugar solutions incorporating solids, therefore obtaining an attractive product capable of enduring storage under environmental conditions without deterioration (Berbari et al., 1992). Also known as sugar saturation, and also called glazing, is considered a secular art. This process is widely used as a conservation method of fruits, vegetables, flowers, etc, for future use in industrialized formulation of foods, such as cakes, candies, sweets and special breads, being ready for consumption such as the case of entire or cut fruits and also having medicinal functions, such as fruits and for ornamentation in the case of flowers (Park et Al., 1980). The maturation state of the plant, as well as its consistency are influential factors in the amount of sugar needed for the crystallization process (Sabaa-Srur, 1996). Cruess (1973) reports that mature fruits are not appropriate for sugar saturation, unless it is previously treated with salts, which by removing water causes rigidness of fruit structure, or by using calcium chloride.

Fruit and vegetable processing aims basically to expand consumption shelf-life, preserving quality through inhibition of possible deteriorating processes. The success of the conservation unites a series of factors ranging from the choice of the product, hygiene considerations, to the final preparation. In order for the product to have good quality it is necessary that it maintains its maximum nutritional and sensorial characteristics (aroma, flavor and color); therefore, factors that might contribute to its deterioration, whether microbial, chemical or enzymatic, must be eliminated (Torrezan, 1997).

During the years, many progress has been made regarding the elucidation of the importance of some parameters in the process of fruit saturation with sugar, whereas it can be concluded that the composition of the syrup at the end of the process contains a mixture of at least two different sugars, whereas the most indicated are sucrose and glucose (Brown, 1996). Specifically, glucose reduces sucrose crystallization and improves appearance and flavor of the final product. Temperature can be increased to facilitate sugar penetration in the fruit. It should be maintained between 55 and $60{ }^{\circ} \mathrm{C}$, so it will not promote sucrose inversion and indiscriminated caramelization; both undesirable. The proper ratio between reducing sugars and non-reducing is also essential in the crystallization process, thus the process in which fermentation occurs, one should avoid adding glucose over the same, because the inversion reaction of sucrose provides invert sugar, which would result in a high concentration of sugars in the final product, resulting in flaccid products with texture. However, for those procedures that employ preservatives recommended by the addition 
of $5 \%$ glucose throughout the stages of the process until reaching the limit of $25 \%$ reducing sugars (Teixeira et al., 1987). In Brazil there is not a lot of crystallized fruit production, whereas only a few big industries process these kinds of products in a more technified manner and offer is greater than the demand. The internal consumer market can absorb all the production, whereas around $70 \%$ is used in the formulation of bakery products and ice cream parlors and the rest is destined directly to consumers with no exportation of crystallized fruits (Berbari et al.,1992). This way, given the absence of information in the specialized literature, this study aimed at to use fruits of cactus pear fruit to prepare jellies, as well as to analyze sensory the acceptance of this product and elaboration of crystallized cactus pear fruit and sensorial evaluation of some attributes as well as intention of buying.

\section{Material and Methods}

Fruits from an intensive plantation located in the county of Ourolândia, Bahia, which were taken to the Food Technology Laboratory of the Center of Agricultural, Environmental and Biological Sciences of the Federal University of the Reconcave of Bahia in Cruz das Almas, were used. Fruits were washed in chlorate water, cut with steel knives and the pulp and seeds separated and cut into cubes. Three treatments were used: T01, pulp with addition of $0.2 \% \mathrm{CaCl}_{2} ; \mathrm{T} 02$, pulp without the addition of $\mathrm{CaCl}_{2}$ and $\mathrm{T} 03$, peel without the addition of $\mathrm{CaCl}_{2}$. These were cooked in sugar syrup (sucrose) and glucose with initial concentration of $20 \%$ gradually increasing $10 \%$ of sugar every 24 hours until saturation ( $70 \%$ of sugar). After saturation, partial drainage of the syrup was carried out and the slices quickly immersed in hot water and dehydrated in stove with heated air circulation at $50{ }^{\circ} \mathrm{C}$. Once partially dried, they were immersed for $5 \mathrm{~min}$. in saturated sucrose syrup and dehydrated under same conditions. The final product obtained was wrapped in plastic containers of $500 \mathrm{~mL}$, placed in cardboard boxes and stored at room temperature $\left(30^{\circ} \pm 3{ }^{\circ} \mathrm{C}\right)$. Sensorial analysis comprised of acceptability testes with 30 non trained judges of both sexes with ages between 16 and 45 years using the 9-point structured hedonic scale anchored in its extremes the terms like extremely 9 and dislike extremely 1 and intension of buying according to Moraes, (1988). Samples weighing approximately
$20 \mathrm{~g}$ were served at room temperature in disposable plastic cups coded with three digit numbers with random order of presentation, and water for palate cleansing between sample evaluations. Time of sampling was between 9 and 12 am and 2 and $5 \mathrm{pm}$. The following parameters were evaluated: overall acceptance, aroma, flavor, color and texture. Data was processed using the SISVAR, statistical package Ferreira, (2000), calculated from the average of the grades obtained. Sensorial profile analysis was carried out for the samples using the spider graph. Statistical significance of the differences between averages was determined using the Tukey test at $5 \%$ probability. To obtaining the jelly of cactus pear fruit, were used fruits at the coming of a commercial plantation ripe stadium, located in the town of Jacobina-Ba, $11^{\circ} 04^{\prime \prime} 25^{\prime}, 3$ South latitude and longitude $40^{\circ} 43^{\prime \prime} 07^{\prime}, 3$ West. After having picked and selected, they were storage in isopor box and led to Food Technology Laboratory of the Center of Agricultural, Environmental and Biological Sciences of the Federal University of the Reconcave of Bahia in Cruz das Almas. The fruits were washed with solution to $2 \mathrm{ppm}$ of hypochlorite of sodium, washed in running water and placed in trays for the dry. For the extraction of the pulp, the fruits were peeled manually, with I aid of knives of stainless steel and the peel was removed, for soon after, they be cut for the removal of the seeds. This way, the pulp was separate with use of a plastic sieve of fine mesh that after having homogenized was used for the elaboration of the jelly. For the obtaining of the jelly, the obtained juice was submitted to the cooking $\left(100^{\circ} \mathrm{C}\right)$, being added then of sugar in the proportion $1: 1$, for obtaining of jelly extra type, $0,1 \%$ of potassium sorbato and $1 \%$ of citric pectin in relation to total mass and $0,5 \%$ of citric acid, second (Jackix, 1988). The total time of cooking was of 10 minutes, so that it happened inversion of part of the sucrose (Albuquerque, 1997). The following analyses physical-chemistries were accomplished: total soluble solids (TSS), total tritable acidity (TTA) humidity, sugar reducer and $\mathrm{pH}$. In the sensorial analysis they not participated of the tests 20 fitting room, of both age group sexes that it oscillated of 20 and 50 years. Each sample was served in glasses of plastic disposable, of white color, accompanied of the evaluation record. In the Test of Acceptability, the scale hedonic of 9 points was used, anchored in your ends in the terms I liked very much [9] and I displeased very much [1]. The 
Table 1. Average of crystallized sweet attributes in cactus pear fruit.

\begin{tabular}{cccccc}
\hline Treatments & Global Impression & Aroma & Flavor & Color & Texture \\
\hline 1 & $5.4 \mathrm{a}$ & $5.0 \mathrm{a}$ & $5.8 \mathrm{a}$ & $5.6 \mathrm{a}$ & $5.6 \mathrm{a}$ \\
2 & $5.6 \mathrm{a}$ & $5.4 \mathrm{a}$ & $6.3 \mathrm{a}$ & $6.2 \mathrm{a}$ & $6.4 \mathrm{ab}$ \\
3 & $5.4 \mathrm{a}$ & $4.5 \mathrm{a}$ & $5.4 \mathrm{a}$ & $5.3 \mathrm{a}$ & $5.0 \mathrm{~b}$ \\
\hline
\end{tabular}

Averages followed by the same letter in the same column do not differ between themselves at $5 \%$ level of significance (Tukey test).

appraised parameters were: global impression, aroma, flavor, color, texture and intention of in accordance purchase (Moraes 1988). Data was processed using the program SISVAR, Ferreira, (2000).

\section{Results and Discussion}

Table 2 shows the physical-chemical characteristics of crystallized cactus pear fruit. TSS values were $65,4,67,2$ and $68,5^{\circ}$ Brix for the T01, T02 and T03 treatments respectively. This values are similar to recommended by Soler (1991), $65^{\circ}$ Brix. The $\mathrm{pH}$ values were 5.27, 5.54 and 5.47 for the T01, T02 and T03 treatments, respectively. According to (Sabaa-Srur, 1996) the ideal $\mathrm{pH}$ for obtaining crystallized fruits is 4 ; the values of $\mathrm{pH}$ found for three treatments are below the one considered ideal. The values of TTA were 0.05 , 0.05 and $0.06 \%$ for the T01, T02, T03 treatments, respectively. Table 1 and Graph 1 show the results of the sensorial acceptability tests by consumers in order to evaluate the overall impression of the different formulations of cryslallized cactus pear fruit. The average of the grades for treatments T01, T02 and T03 for the overall impression parameter did not differ statistically among each other being this parameter qualified between neither like or dislike and slightly like by consumers. Treatment $\mathrm{T} 02$ had the greatest average 5.6 (whereas $61.11 \%$ of the consumers gave grade 6 to this parameter); the same was observed by the aroma parameter in which the averages did not statistically differ among each other and this parameter was classified by the consumers between neither like or dislike and like slightly. The greatest average was obtained by treatment T02, 5.4. Most consumers, $32.26 \%$ attributed grade 6 to this parameter, like slightly. For the flavor parameter there was no significant difference between treatments whereas this was qualified among the consumers between dislike slightly and neither like or dislike and the greatest average was 6.3 for treatment $\mathrm{T} 02$, whereas grade
Table 2. Physical-chemical characteristics of crystallized cactus pear fruit.

\begin{tabular}{|c|c|c|c|}
\hline Treatmet & $\mathrm{pH}$ & TSS (\%) & $\begin{array}{l}\text { TTA }\left(\mathrm{g} 100 \mathrm{~g}^{-1} \text { of }\right. \\
\text { citric acid) }\end{array}$ \\
\hline T01 & 5.27 & 65,7 & 0.05 \\
\hline T02 & 5.54 & 67,2 & 0.05 \\
\hline T03 & 5.47 & 68,5 & 0.06 \\
\hline
\end{tabular}

7 (like moderately) was attributed to this parameter by $32.26 \%$ of consumers. For the color parameter, also there was no significant difference between treatments, whereas this parameter was qualified between neither like or dislike and like moderately, whereas the greatest average was 6.2 obtained by treatment $\mathrm{T} 02$. The greatest grade in this parameter was 7 (like moderately), attributed to treatment T01 by $35.48 \%$ of consumers. For the texture parameter, treatments T01 and T02 did not differ statistically between each other and there was difference between treatments $\mathrm{T} 01$ and $\mathrm{T} 03$ whereas they were qualified by consumers between neither like or dislike and slightly like. The greatest average obtained was 6.5 for treatment T02 being 7 the greatest grade (like moderately), attributed by $32.26 \%$ of consumers. For the intension of buying test in treatment T01, $9.68 \%$ of consumers declared that they would by the product and $90.32 \%$ would not. For treatment T02, $48.39 \%$ declared that they would by the product and $51.61 \%$ would not. Treatment T03, $22.58 \%$ of the consumers would by the product and $77.42 \%$ would not. In agreement with the Table 3 , it is verified that the obtained jelly, it presented $\mathrm{pH}$ values and TTA equal to 3,07 and $0,63 \%$, respectively. It is known that the acidity and the $\mathrm{pH}$ of the jellies should be controlled. In agreement with Gomes, (2006) the total acidity should not exceed to $0,8 \%$, and the suitable minimum is $0,3 \%$.O same author tells that for the $\mathrm{pH}$ values, the same should not surpass of 3,4 and that below 3,0 happens a tendency to the sinérese. This way, the gel obtained in the present jelly it was not committed with relationship your 
Table 3. Characteristics physical chemistries in jelly cactus pear fruit.

\begin{tabular}{lc}
\hline \multicolumn{1}{c}{ Determinations } & Means \\
\hline Humidity $(\%)$ & 23,5 \\
Sugar reducer $(\%)$ & 21,6 \\
pH & 3,07 \\
TSS $\left({ }^{\circ}\right.$ BRIX) & 69,2 \\
Acidity (citric acid \%) & 0,63 \\
\hline
\end{tabular}

Table 4 . Notes attributed by the fitting room in the sensorial evaluation of jelly in cactus pear fruit.

\begin{tabular}{lccc}
\hline Attributes & $\begin{array}{c}\text { Observed } \\
\text { Averages }\end{array}$ & $\begin{array}{c}\text { Deviation } \\
\text { pattern }\end{array}$ & $\mathrm{CV}(\%)$ \\
\hline Global & 8,0 & 0,7 & 8,8 \\
impression & & 1,03 & 13,7 \\
Aroma & 7,5 & 1,11 & 14,5 \\
Flavor & 7,7 & 0,83 & 10,1 \\
Color & 8,2 & 0,80 & 10,0 \\
Texture & 8,1 & \\
\hline
\end{tabular}

formation nor the elasticity. The value of the total soluble solids was of $69,2^{\circ}$ Brix. As (Jackix, 1988) the great concentration of sugar is around $67,5 \%$, however it is possible to do fruit jelly with less than $60 \%$, since that fruit is rich in pectin. The values found for humidity it was of $23,5 \%$. In agreement with the results found for total soluble solids and humidity, we verified that the respective values

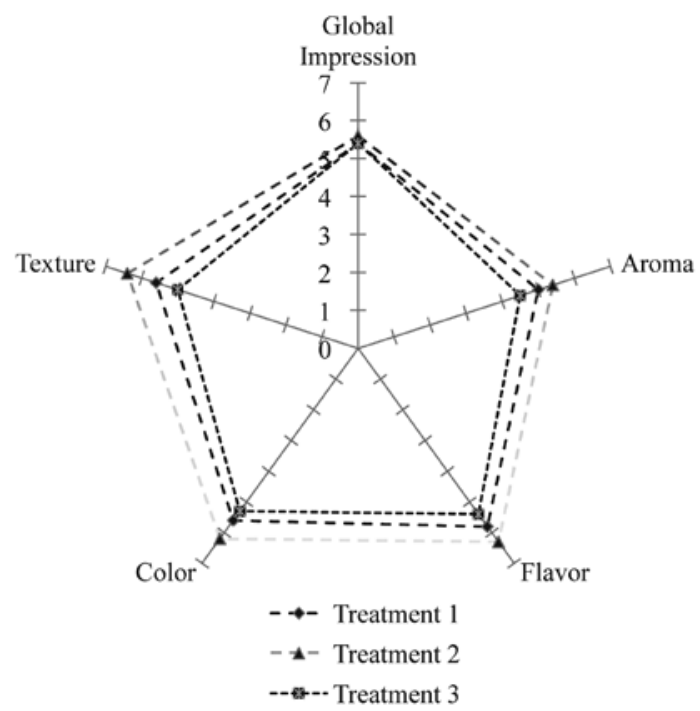

Figure 1. Sensorial profile in spider graph of crystallized cactus pear fruit samples.
Table 5. Percentage of notes attributed by the consumers in the analyzes sensorial of jelly of cactus pear fruit.

\begin{tabular}{cccccc}
\hline Notes & $\begin{array}{c}\text { Global } \\
\text { Impression }\end{array}$ & Aroma & Flavor & Color & Texture \\
\hline 5 & 0 & 4,8 & 0 & 0 & 0 \\
6 & 4,8 & 9,5 & 19,1 & 4,8 & 4,8 \\
7 & 9,5 & 28,6 & 23,8 & 9,5 & 14,3 \\
8 & 66,7 & 42,9 & 28,6 & 42,9 & 52,4 \\
9 & 19,1 & 14,3 & 28,6 & 42,9 & 28,6 \\
\hline
\end{tabular}

are agreement with (Brazil, 1978) that determines a maximum value of humidity of $35 \% \mathrm{p} / \mathrm{p}$ and for total soluble Solids the minimum value $65 \%$. The sugars reducers obtained value of $21,6 \%$ those values they are ideal so that it avoids the crystallization of the sucrose during the storage. In the Table 4 , it is observed that the parameter global impression obtained note 8,0 indicating that the product was well I accept for the fitting room, the low deviation pattern 0,7 indicated that the acceptance variability among the judges for the cactus pear fruit jelly was very small. With relationship to the attribute color, it was observed that was what more pleased to the fitting room obtaining note 8,23 . for This was waited due to the attractive of the cactus pear fruit orange coloration and it showed that the processing didn't destroy the pigments responsible betalains for the color of the fruit. In what refers to the aroma, we verified that presented smaller note 7,5 was; probably this was due to the fact that the fruits " in natura, don't " present pronounced aroma and the process of formation of the jelly possibly the esters that are largely responsible for that parameter has decreased. The flavor obtained note 7,7 and the texture 8,04 . The sensorial analysis demonstrated a great acceptance, and that the percentages of the variation coefficient for the attributes aroma and flavor, came relatively high. Possible È that such variation, be due to the fact, that the appraisers have not had a degree of appropriate sensibility to obtain percentile larger of homogeneity among the attributed notes. In agreement with the Table 5, we can verify that in the general the notes attributed for all the appraised parameters in the scale hedonic, they varied among 5 (no liked/no displeased) and 9 liked very much). Most of the appraisers attributed note 8 for all the attributes with prominence global impression, $66,7 \%$ and texture $52,4 \%$. In what refers to the test of purchase intention, $100 \%$ of the fitting room will declare that would buy the product. 


\section{Conclusions}

Treatment without calcium chloride presented best grades for the sensorial attributes evaluated.

Results demonstrate that consumers presented greater intention of buying of $48.39 \%$ for treatment without calcium chloride.

It is possible that the elevated acceptability of this treatment when compared to the others, may be due to consumer preference regarding less consistent sweets.

The cactus pear fruit present good potential for the elaboration of jellies, being necessary the acid addition, for the fact of the fruit to possess high $\mathrm{pH}$, as well as the pectin addition.
The characteristics physical-chemistries of the obtained jelly, this in agreement with the established values for the effective legislation for that product type in Brazil.

The jelly presented good sensorial acceptance, and enter adult's attributes and smaller acceptance they were the color and the aroma respectively. All the consumers declare purchase intention in the product.

The production of cactus pear fruit jelly was shown technologically viable, and certainly it represents one more economical option to the small producing of the semi-arid areas of the northeast of Brazil.

\section{Literature Cited}

Albuquerque, J.P.; Nacco, R.; Faro, A.

1996. Avaliação global de geléias de uva através do método de dados difusos. Ciência e Tecnologia de Alimentos, Campinas, 16 (3): 250-254.

Berbari, S.A.G.; Menegale, L.L. De C.; Almeida, M.E. de. 1992. Processamento e controle de qualidade de frutas cristalizadas. Higiene Alimentar, 6 (24): 28-36.

Brasil

2000. Ministério da Saúde. Secretaria de Vigilância Sanitária. Aprova Normas Técnicas Especiais do Estado de São Paulo, relativas a alimentos e bebidas. Resolução da Comissão Nacional de Normas e Padrões para Alimentos-CNNPA n. 12, de 24 de julho de 1978.

Brow, B.I.

1969. Processing and preservation of ginger by syruping under atmospheric conditions, Food Technol., 23: 87-91.

Cruess, W.V.

1973. Produtos Industriais de Frutas e Hortaliças. São Paulo: Edgard Blücher, v. 2, 854 p.

Ferreira, D. F.

2000. Análises estatísticas por meio do Sisvar para Windows versão 4.0. In: Reunião Anual da Região Brasileira da Sociedade Internacional de Biometria, 45, 2000, São Carlos, Resumos... São Carlos: UFSCar, pp. 255-258.

Gomes, M.V.J Do.; Raupp, D. da Silva.; Chaimsohn, F.P.; Borsato, A.V.

2006. Processamento de conservas de palmito caulinar de pupunha contendo diferentes graus de acidez. Ciência $e$ Agrotecnologia, 30 (3), 569-574.
Granada, G.G.; Zambiazi, R.C.; Mendonça, C.R.B.

2004. Abacaxi: produção, mercado e subprodutos. Boletim do Centro de Pesquisa e Processamento de Alimentos, Curitiba 22 (2): 405-422.

Jackix, Marisa Hoelz

1988. Doces, geléias e frutas em calda. Campinas, SP: Editora da UNICAMP, $85 \mathrm{p}$.

Manica, I.

2002. Frutas nativas, exóticas e silvestre 2..Técnicas de produção e mercado. feijoa, figo- da- índia, fruta pão, jaca, lichia, mangaba. Porto Alegre. Ed. Cinco Continentes, 541 p.

Moraes, M.A.C.

1988. Métodos para a avaliação sensorial dos alimentos. 7.ed. Campinas: Unicamp, 93 p.

Park, Y.K.; Sato, H.H.; Almeida, T.D.; Moretti, R.H.

1980. Polyphenol Oxidase of Mango (Mangifera indica var Haden). Journal of Food Science and Technology, 45 (6): 1619-1621.

Sabaa-Srur, A.U.O.

1996. Saturação de Vegetais com Açúcares. Seropédica -RJ: Imprensa Universitária-UFRRJ, 14 p.

Teixeira, E.; Meinert, E.; Barbetta, P.A.

1987. Análise sensorial dos alimentos. Florianópolis: ed. da UFSC, $180 \mathrm{p}$.

Torrezan, R.

1997. Curso de processamento de frutas, Rio de Janeiro: CTAA-Embrapa, 137 p. 